\title{
Lip and Oral Cavity Cancer pT4b TNM Finding $\mathrm{v} 7$
}

National Cancer Institute

\section{Source}

National Cancer Institute. Lip and Oral Cavity Cancer pT 4b TNM Finding v7. NCI

Thesaurus. Code C88948.

Lip and oral cavity cancer with very advanced local disease. Tumor invades masticator space, pterygoid plates, or skull base and/or encases internal carotid artery. (from AJCC 7th Ed.) 